\title{
The Investigation of Effective Parameters on Trip Length of Bikesharing Systems (BSS)
}

\author{
Bisiklet Paylaşım Sistemlerindeki Yolculuk Uzunluğu Üzerinde Etkili Parametrelerin \\ Incelenmesi
}

\author{
Metin Mutlu AYDIN*1,a , Mehmet Sinan YILDIRIM ${ }^{2, b}$ \\ ${ }^{I}$ Gümüşhane University, Faculty of Engineering and Natural Sciences, Department of Civil Engineering, 29100, Gümüşhane \\ ${ }^{2}$ Manisa Celal Bayar University, Faculty of Engineering, Department of Civil Engineering, 45140, Manisa
}

\begin{tabular}{|c|c|c|}
\hline - Geliș tarihi / Received: 26.04 .2018 & - Düzeltilerek gelis tarihi / Received in revised form: 10.07.2018 & - Kabul tarihi / Accepted: 22.07.2018 \\
\hline
\end{tabular}

\begin{abstract}
Various bike sharing systems (BSS) were designed and used in different cities of the world in the past decade. Many benefits of the BSS have supplied a rapid growth of this transport mode in all around the world. BSS mainly have many benefits such as traffic (flexible mobility and multimodal transport connections), health (physical activity) and cost (low trip cost). Also a planned BSS can serve an easy access to other public transportation system and can be an important actor of the public transportation system. Especially in many big cities, bike sharing systems becomes an important part of the public transportation and ensure short travel times to users. However, the growing may causes many problems such as demand, safety, effectiveness, cost etc. For this purpose many studies have conducted by the planners, researchers and decision makers to find best solutions to mentioned problems. In the scope of this study, the relation among average temperature, trip length and trip number was examined for a bike sharing system. For this purpose, Capital Bikeshare system (Washington, D.C., Arlington and Alexandria, VA and Montgomery County, MD) is chosen as pilot system to investigate. Study results showed that there is a strong and positive correlation among temperature, trip number and trip length. Additionally, it was obtained that bicycle utilization has a maximum value between 5-10 minutes. This results can be caused by the free utilization duration (30 minutes) of the system for the members.
\end{abstract}

Keywords: Bike sharing systems, Public transportation, Transport mode, Trip length distribution

$\ddot{\partial} z$

Son on yılda dünyanın farklı şehirlerinde değişik bisiklet paylaşım sistemleri (BPS) tasarlanmış ve kullanılmıştır. Birçok fayda sağlayan bu bisiklet paylaşım sistemleri ile bisiklet ulaşım modu tüm Dünya'da hızlı bir büyüme göstermiştir. BPS temel olarak trafik (esnek mobilite ve çok modlu ulaşım bağlantılart), sağlık (fiziksel aktivite) ve fiyat (düşük yolculuk maliyeti) gibi birçok fayda sağlamaktadır. Ayrıca planlanmış bir BPS diğer ulaşım modlarına kolay bir ulaşım sağlayabilmekte ve toplu taşıma sistemlerinde önemli bir aktör olabilmektedir. Özellikle büyükşshirlerde BPS, toplu taşıma sistemlerinin önemli bir parçası olarak, kullanıcılara kısa yolculuk süreleri sağlamaktadır. Bununla birlikte bu sistemlerin büyümesi talep, güvenlik, efektif olmama, maliyet vb. bazı sorunların ortaya çıkmasına da sebep olabilmektedir. Bu amaçla belirlenen problemlere en iyi çözümü bulabilmek amacıyla planlayıcılar, arașttrmacılar ve karar vericiler tarafindan birçok araştırma yürü̈tülmektedir. Bu çalışma kapsaminda ise sıcaklık, yolculuk uzunluğu ve yolculuk sayısı arasındaki ilişski bir bisiklet paylaşım sistemi için detaylı olarak incelenmişstir. Bu amaçla Capital Bisiklet Paylaşım Sistemi (Washington, D.C., Arlington and Alexandria, VA and Montgomery County, MD) incelenmek amacıyla pilot sistem olarak seçilmiştir. Çalışma sonuçları sicaklık, yolculuk sayısı ve uzunluğu arasında güçlü ve pozitif bir ilişsi olduğunu göstermiştir. Ilaveten incelenen BPS'de bisiklet kullanımının en çok 5-10 dakika arasında olduğu sonucuna ulaşılmışıtır. Bu sonuç üzerinde en etkili olan parametre ise bisiklet kullanımının ilk 30 dakika ücretsiz olmasl gösterilebilmektedir.

Anahtar kelimeler: Bisiklet paylaşım sistemleri, Toplu ulaşım, Ulaşım modu, Yolculuk uzunluğu dağıllımı

\footnotetext{
*a Metin Mutlu AYDIN; metinmutluaydin@gmail.com; Tel: (0506) 26991 49; orcid.org/0000-0001-9470-716X

${ }^{\mathrm{b}}$ orcid.org/0000-0001-5347-2456
} 


\section{Introduction}

The first Bike Sharing System (BSS) was used in the Netherlands in the 1960s (DeMaio, 2009; Shaheen et al., 2010). Since then, many bike sharing systems were designed and used in different cities of the world. There is a great development on bike sharing systems over the past few years (Fishman, 2015) and bike sharing systems are becoming very popular part of shared or multimodal transportation in the past decade (Ranaiefar and Rixey, 2016; Ghasemlou et al., 2015). Many benefits of the BSS have supplied a rapid growth of this transport mode in all around the world. Current statistics shows that there are more than 1000 cities have already started or considering the application of BSS in at least 49 countries with one million shared bikes in 2015 (Meddin and DeMaio, 2015; Metrobike, 2015; Wikipedia, 2015).

BSS mainly have many benefits such as traffic (flexible mobility and multimodal transport connections), health (physical activity) and cost (low trip cost) (Shaheen et al., 2010). Additionally, these systems supply a healthier and short trip facilities especially in big (metropolitan) cities. Also a planned BSS can serve an easy access to other public transportation systems (İmani and Elaru, 2016; Jäppinen et al., 2013) and can be an important actor of the public transportation system. On the contrary of other transportation model bicycle has no safety. Current traffic accident statistics shows that many bicycle users are dying in every year caused by the carelessness of the other vehicle drivers (Ghasemlou et al., 2015). Previous research results showed that BSS is a successful tool for improving of drivers' awareness towards bicycle users. Consequently, it helps to increase the safety for cyclists (Murphy and Usher, 2015).

Bike sharing systems has a great effect on the utilization of bicycle a public transport mode (Shaheen et al., 2013). Over the past years, many studies were conducted to examine effective parameters on bike sharing flows, demands and utilization (Gregerson et al., 2010; Nair et al., 2013; Buck and Buehler, 2012; Krykewycz et al. 2010; Rixey, 2013; Zhang and Mi, 2018; Zhang et al., 2018; Saplığlu and Aydın, 2018; Otero et al., 2018). Nair et al. (2013) examined various factors on bike sharing system such as system characteristics, the connection of system with public transit network. In another study, Buck and Buhler (2012) investigated the effect of bicycle lane, population, car ownership and public transit facilities on bicycle flows of Capital bike sharing system in Washington DC. Rixey (2013) explored effective all critical factors on bike sharing systems. He found population, job density, income levels as critical factors. Faghih-Imani et al. (2014) studied the impact of land use and urban form attributes on BSS utilization. They have found that BSS stations in areas with higher population density or using interest such as restaurants, stores and universities have higher arrivals and departures. Also many conducted studies found temperature and humidity as critical and effective parameters on performance of bike sharing systems (BSS) (Gebhart and Noland, 2014; Faghih-Imani et al., 2014; El-Assi et al., 2017). In another study, Shaheen et al. (2013) investigated that best station settlement, safety and technological management issues as important parameters on bike sharing systems. According to analysis results, pricing structures and customer base found remarkably similar in public bikesharing systems. Also it was found that there is an even greater diversity of funding sources, operational settings, and business models (Shaheen et al., 2013).

Bicycle sharing systems are actively used in all different metropolitan cities in all over the world such as New York, Vienna, Copenhagen, Helsinki, Amsterdam, Marseille, Budapest, Montreal, Rio de Janeiro, Beijing, İstanbul etc. These systems are actively used in Turkey and especially in warmer climate cities such as Eskişehir, İskenderun, Kocaeli, Konya, Muğla, Trabzon, Antalya, Kayseri etc. In this paper, to examine the relation between trip length distribution, bike sharing demand and temperature effect Capital Bikeshare Systems which puts over $3100+$ bicycles for the utilization from over the 370 stations across Washington, D.C., Arlington and Alexandria, VA and Montgomery County, MD were chosen as an example bikesharing system for the investigation. In the analysis, compiled data were used from minute by minute readings of bicycle availability at 397 stations on the Capital Bikeshare Systems website in 2015. To evaluate the performance of Capital Bikeshare system, average trip length and distribution, relation among temperature, trip number and trip length was examined.

\section{Data Collection}

In this study, The Capital Bikeshare System (CBS) is chosen as an example bikesharing system for the investigation. Because Capital Bikeshare System is the one of the largest and 
longest public bicycle-sharing systems around the world (Figure 1) and system data is available on its online website (as daily, monthly, quarterly and yearly). Additionally, weather conditions data of the Capital Bikeshare System cities can be obtained from United States National Oceanic and Atmospheric Administration (NOAA).In the study, all necessary data were obtained from the CBS and NOAA's online websites digitally.

Capital Bikeshare System opened on September 20, 2010 with 1,100 bikes at 114 stations - 100 in all eight wards of the District of Columbia and 14 in Arlington (Crystal City, Pentagon City and Potomac Yard). In August 2012, the City of Alexandria, VA joined with eight stations and in September 2013, Montgomery County, MD joined with 51 stations in Bethesda, Friendship Heights, Silver Spring, Takoma Park, Rockville and the Shady Grove Life Sciences Center areas. Nowadays, this system offers over 397 stations and $3100+$ bicycles (see in Table 1).

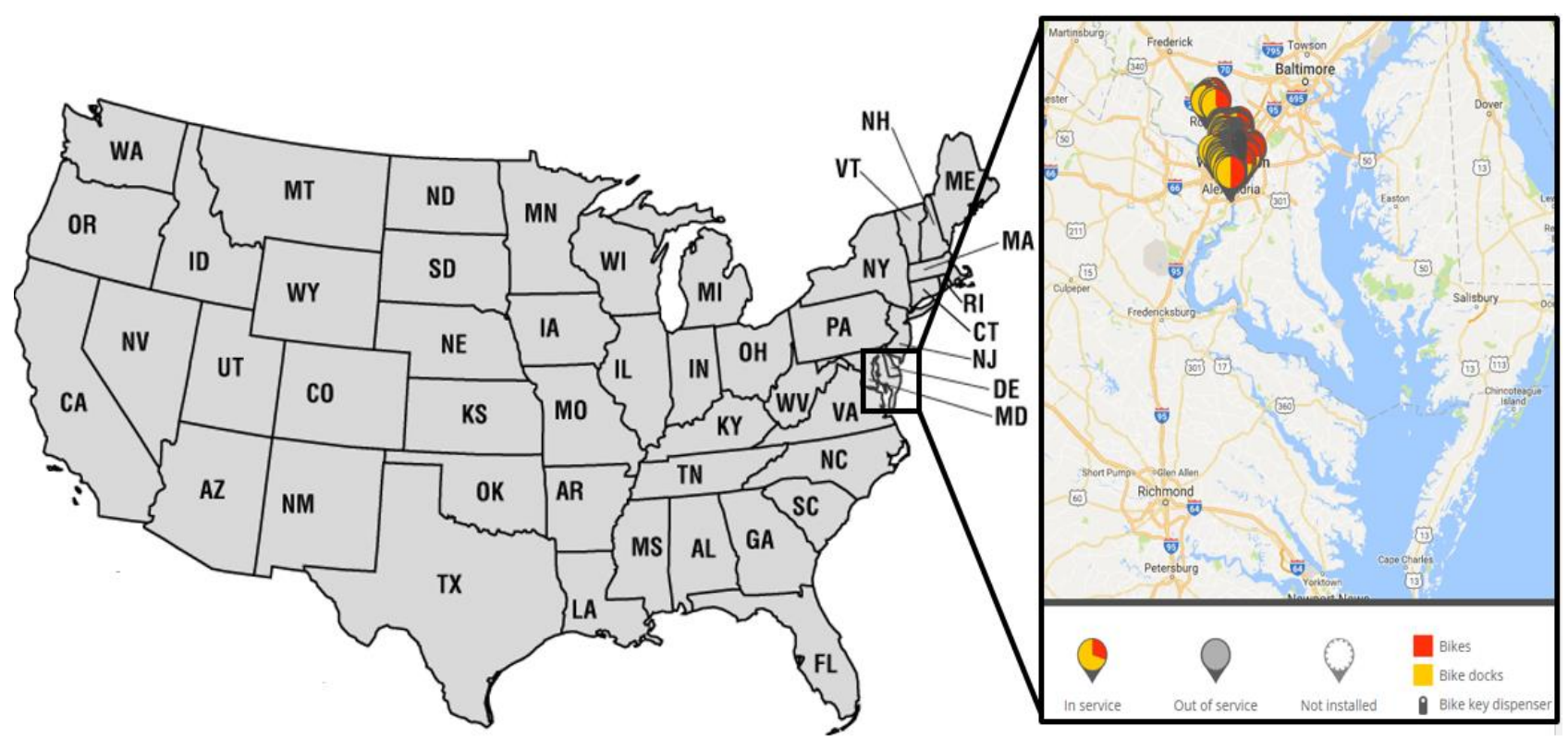

Figure 1. Data collection site of Capital Bikeshare System.

Table 1. Growth of stations (Capitalbikeshare, 2017).

\begin{tabular}{lll}
\hline Year (Between September-August) & Current Stations & New Stations \\
\hline $1(2010-2011)$ & 114 & - \\
\hline $2(2011-2012)$ & 189 & 74 \\
\hline $3(2012-2013)$ & 248 & 60 \\
\hline $4(2013-2014)$ & 337 & 88 \\
\hline $5(2014-2015)$ & 355 & 18 \\
\hline $6(2015-2016)$ & 397 & 43 and counting \\
\hline
\end{tabular}

The current BSS is set up around the chosen cities' main commercial business districts and some residential areas with total 3.185,118 and an average daily ridership of 8,726 trips (Figure 2).

The benefits of capital bike share is summarized by the system authority as given below:

Using Capital Bikesharing System bicycle users can supply various benefits and can made different activities as given below:
- Go to business meetings.

- Skip parking cost,

- Skip traffic problem,

- Get exercise on your way to work and save your healthy,

- Expand your lunch options by using bicycle

- Ride to many sport and social activity,

- Visit your favorite places, 


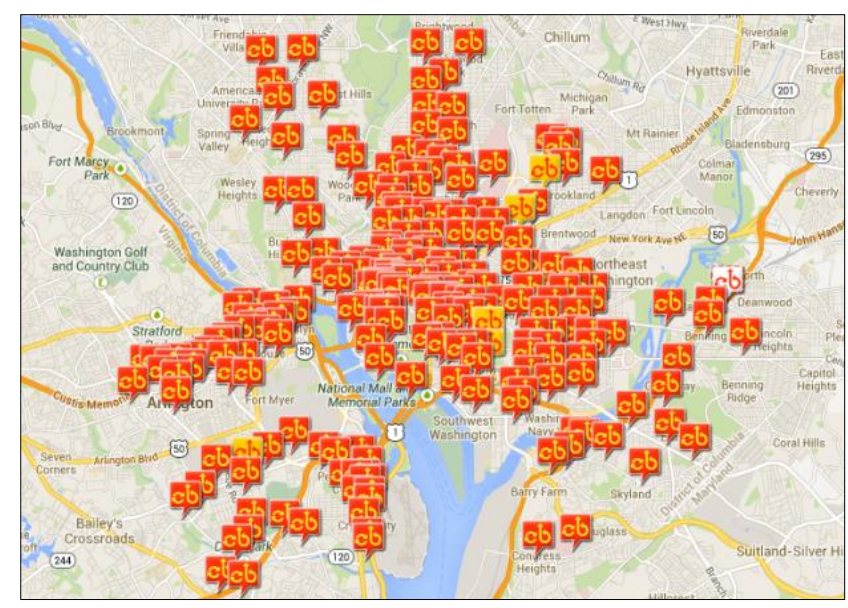

(a)

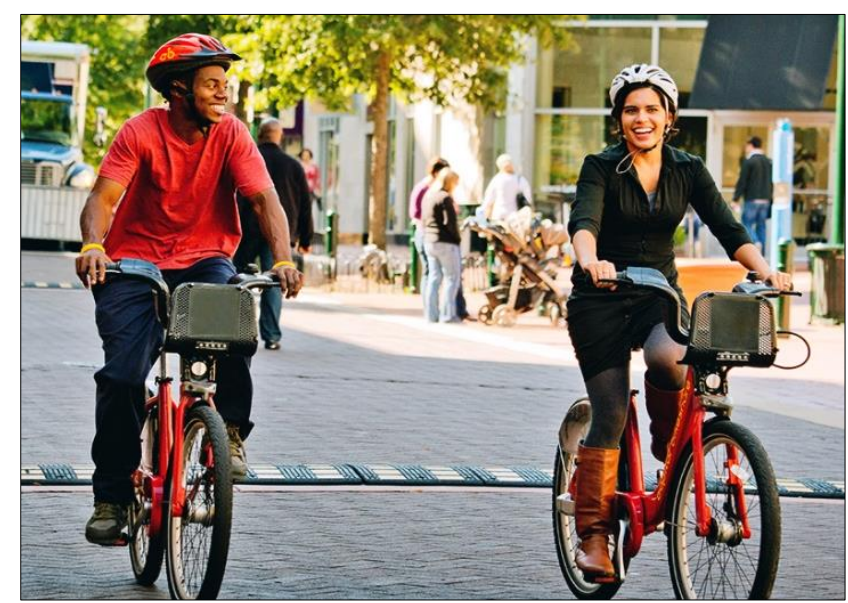

(c)

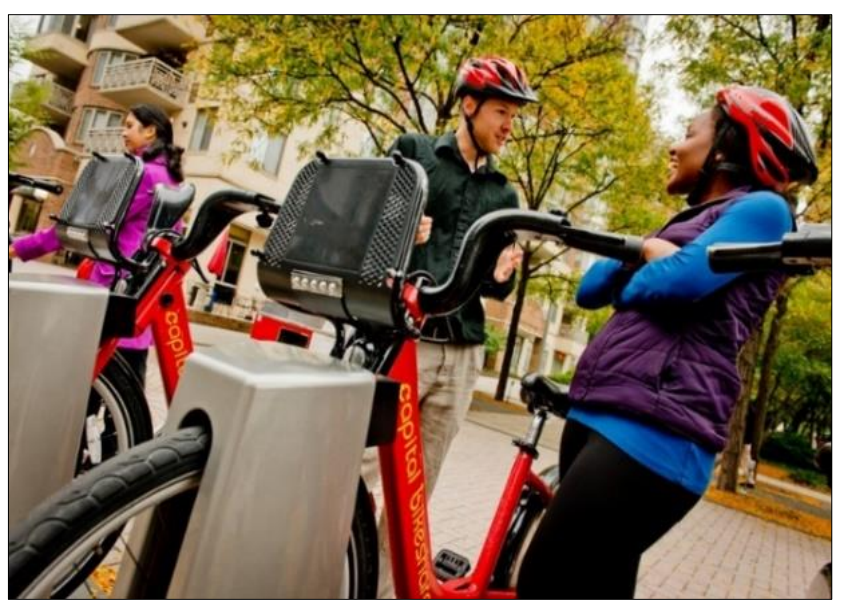

(b)

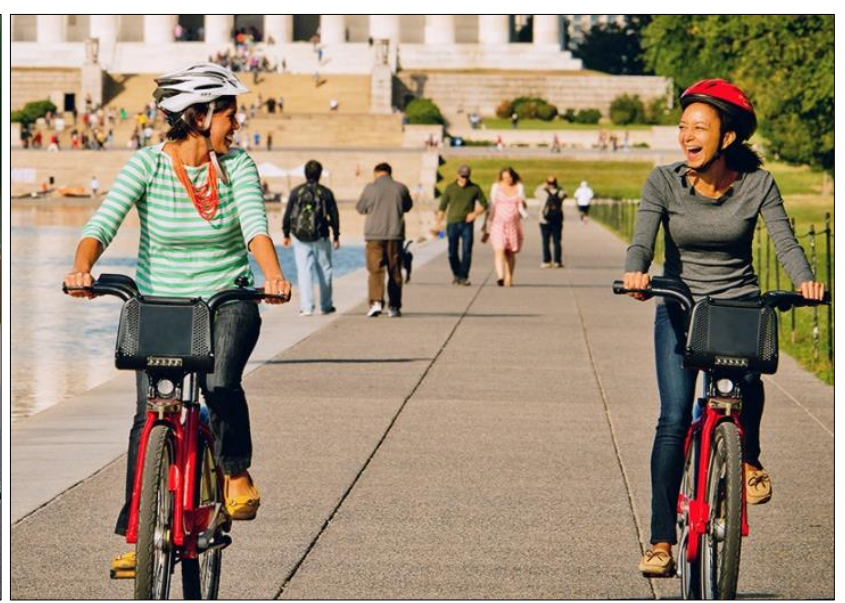

(d)

Figure 2. An example to (a) all stations, (b) one of the current stations (c-d) utilization of the system (Capitalbikeshare, 2017).

Also the safety properties of the system is determined and summarized by the authorities as given below:

- LED lights in front and rear flashing,

- Reflectors and reflective bands on both tires,

- Safety and quality helmet,

The total number of annual and 30-day members of the system is 30,556 (as of July1, 2016). The data and other informations used in our research was obtained from Capital Bikeshare website https://www.capitalbikeshare.com (Figure 3). The capital Bikeshare website provides trip dataset for every 3 months of the operation since 15 September 2010. The trip dataset of system users includes:

- Monthly trip numbers,

- Origin/Destination of trips,
- Origin/Destination of trips according to stations,

- Time Interval per trips,

- Percentage of bicycle trips per time interval,

- Total length (Miles) travelled per Month

Additionally, the capacity and locations of current stations as well as trip duration are also provided in the dataset and weather information was used in the analysis obtained from the National Climatic Data Center (NCDC) for 2015.

\section{Data Analysis and Findings}

In our study, a systematic method was used to demonstrate trip length distribution in Capital Bike sharing systems. For this purpose, firstly the distribution of BSS utilization is classified as hourly-trip number for all stations for monthly data in 2015 as can be seen in Figure 4. 


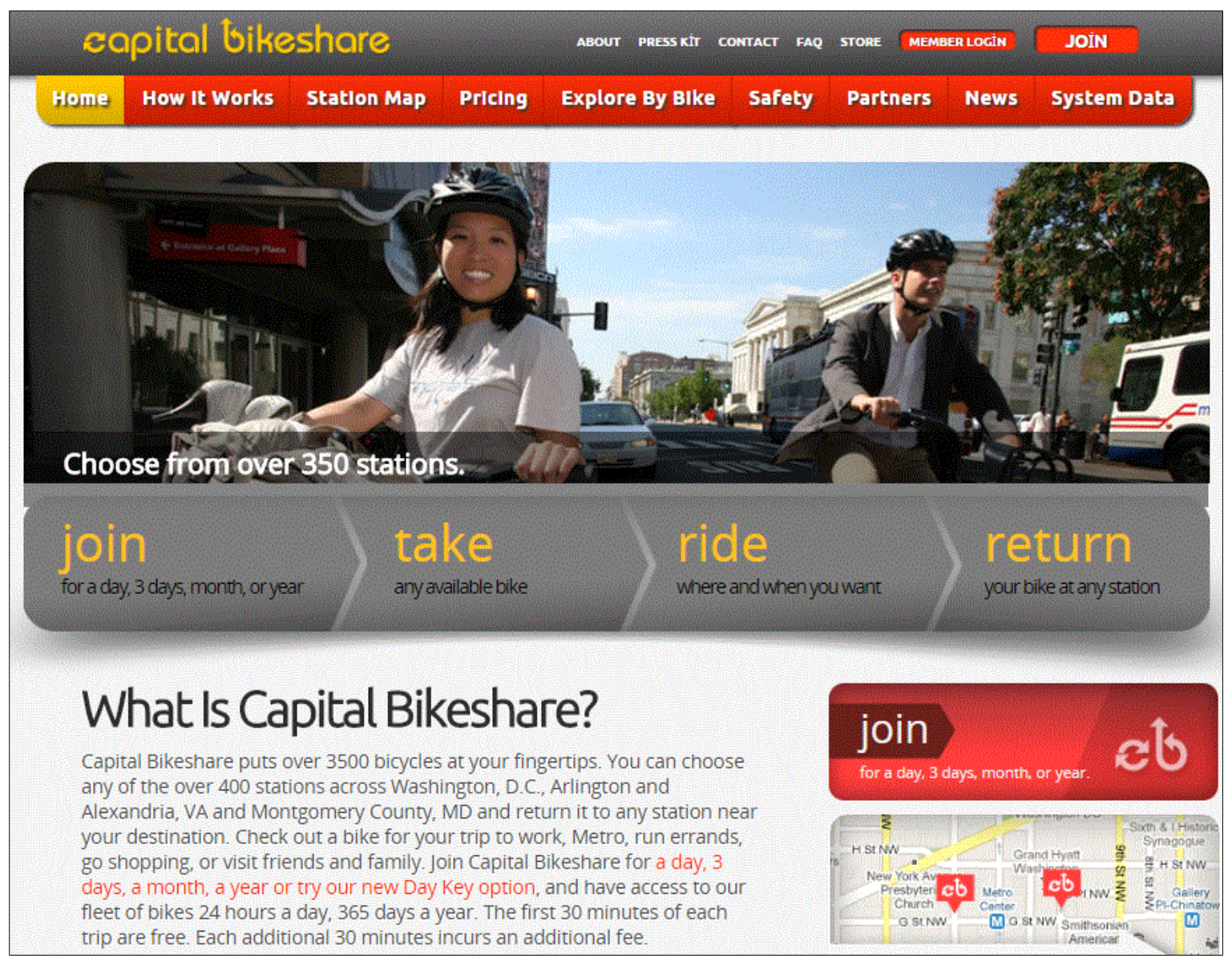

Figure 3. The main webpage of the Capital Bikeshare system (Capitalbikeshare, 2017).

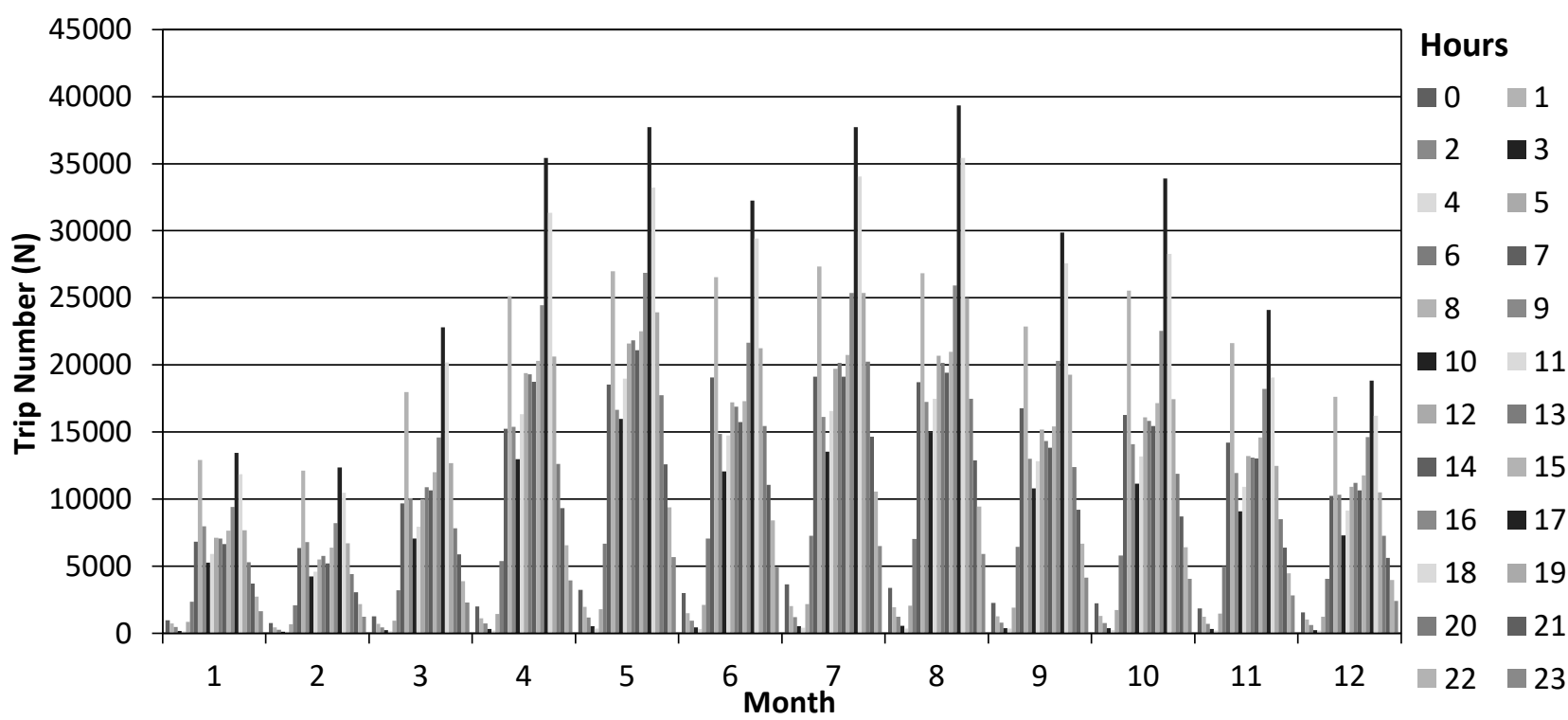

Figure 4. Trip number-Trip hour distribution of Capital Bikeshare system in 2015.

Figure 4 shows that trip numbers have three peak times (Morning-Afternoon-Evening) in a day. From the analysis, peak hours were obtained for morning between 07:00-08:00, for afternoon 12:00-13:00 and for evening 17:00-18.00. In another analysis, trip number distribution (\%) was determined according to hourly data (Figure 5). It is clearly seen from the Figure that the highest peak hour for bicycle utilization was obtained as between 17:00-18:00. In the second order, it was found as between 07:00-08:00. According to Figure 5, hourly bicycle utilization for Q1 months 
(January, February and March) has the same characteristics with Q4 months (October, November and December). It means that effects of weather conditions in another words seasonal effects are a critical parameter on bicycle utilization for users. Additionally, Q2 months (March, April and May) and Q3 months (June, July and August) have the similar trip distributions.

In Figure 6, seasonal average trip length distribution (minutes) was given to examine effects of weather conditions Figure shows that
Q1-Q4 and Q2-Q3 has the same characteristics as similar in Figure 5. According to obtained results from the generated graph, trip length distribution (minutes) can be aligned approximately as Q1 < Q4 $<$ Q3 $<$ Q2. This comparison provides strong evidence in support of seasonal effect on bicycle utilization hypothesis. Additionally, it can be noted that bicycle utilization has a maximum value between 5-10 minutes. This can be caused by the free utilization duration ( 30 minutes) of the system for the members. Therefore, riders use this system for their short trips as free of charge.

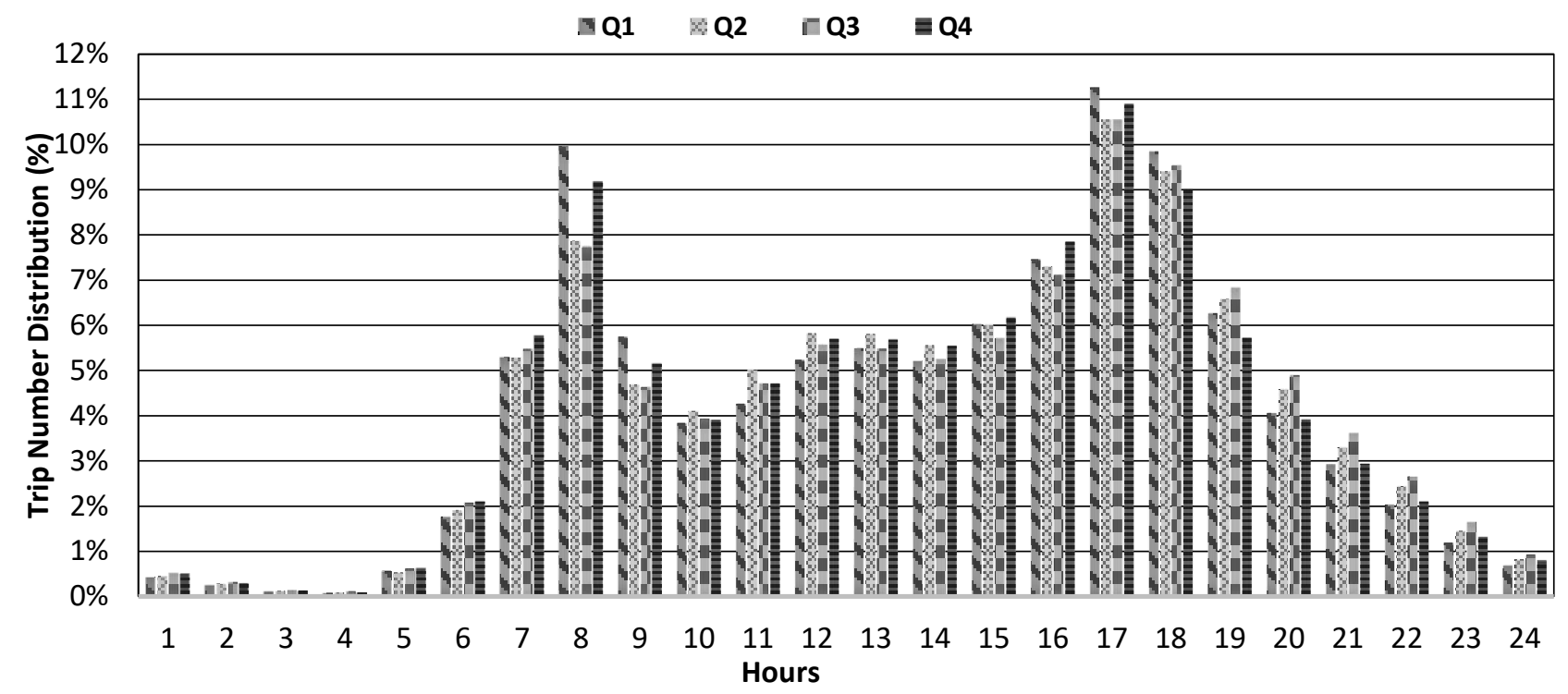

Figure 5. Seasonal Hourly trip distribution (\%) for capital bike sharing system in 2015.

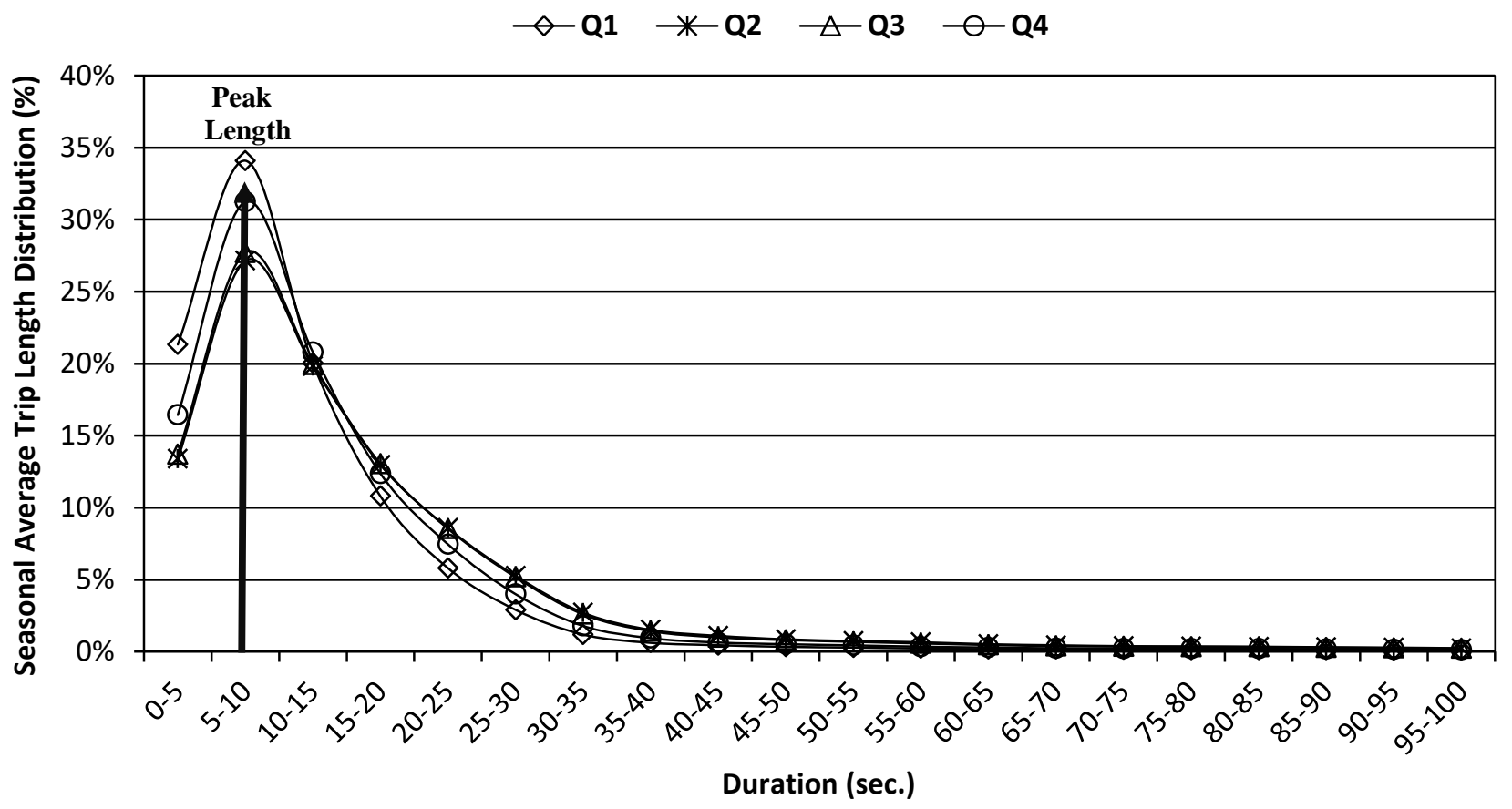

Figure 6. Seasonal average trip length distribution (\%) for capital bike sharing system in 2015 
According to generated graph obtained average trip length distribution was given in Figure 7. Figure shows that users have higher average trip lengths (minutes) for Q2 and Q3 months according to Q1 and Q4 months. Also results shows that users have more bicycle utilization tendency in Q2 and Q3 months. Additionally, it can be seen from the figure that all users have higher trip length generally in afternoon hours.

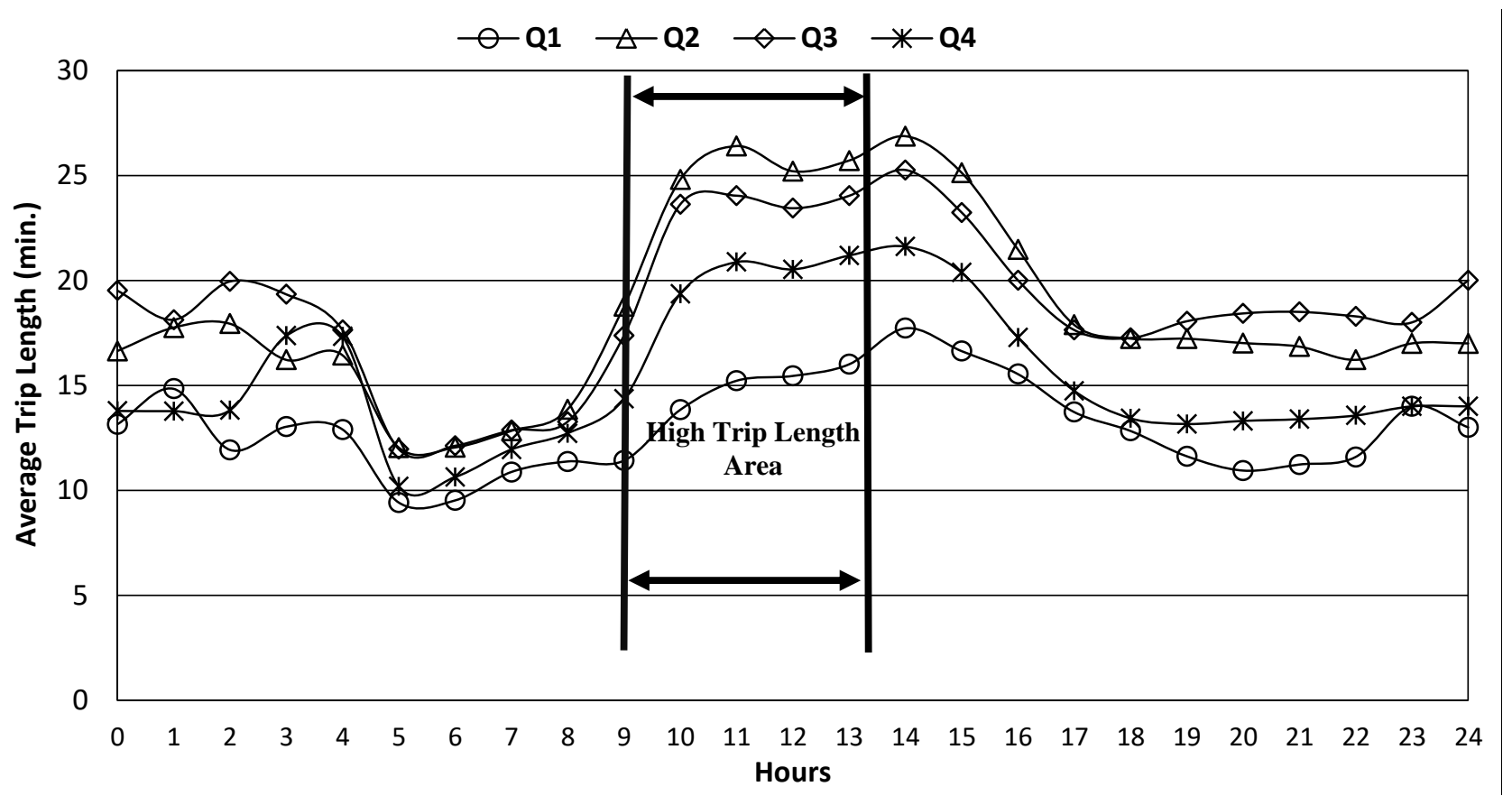

Figure 7. Changing of average trip length for 24 hours for year 2015.

The relation among trip numbers, average monthly temperature (obtained from United States National Oceanic and Atmospheric Administration) and months are shown in Figure 8. It is clear from the figure that temperature is a crucial parameter on bicycle utilization as mentioned before. Because, monthly change in trip numbers has a high and positive correlation between weather conditions.

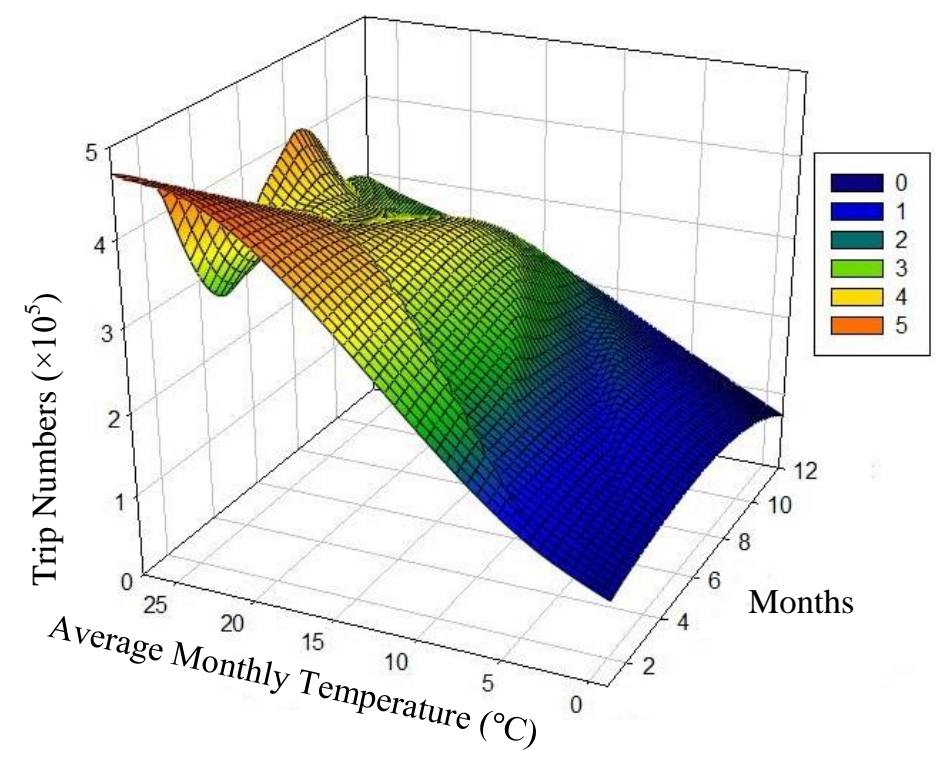

Figure 8. The relation among trip number, average monthly temperature and months. 
Study findings also shows that there is a strong correlation between trip numbers on weekdays and weekend, and temperature (Table 1). Trips on weekends have higher and positive correlations than on weekdays. Also, it can be noted that correlations between trip numbers and temperature for weekends $(\mathrm{r}=0.797)$ and weekdays $(r=0.798)$ have approximately the same values. However correlations between trip length and temperature shows differences for weekend and weekdays. Trip length-Temperature correlation for weekends have higher value $(\mathrm{r}=0.731)$ than for weekdays $(\mathrm{r}=0.611)$.
It can be concluded that trip length of bicycle users on weekends are affected highly from the temperature (weather conditions) (Figure 9). Also results shows that on weekends bicycle users have longer trip lengths than on weekdays for the same weather conditions. This situation shows that users choose longer trips caused by the having more free times on weekends. On the contrary, in weekdays users must reach to work or home generally in a current time. For this purpose they choice bicycle as a transportation mode to reach the work or home for shorter times.

Table 1. Simple correlation coefficients (r) among temperature, trip number and length for weekdays, weekend and all year.

\begin{tabular}{ccccc}
\hline \multirow{4}{*}{ Weekdays } & Variables & Temperature & Trip Number & Trip Length \\
\cline { 2 - 5 } & Temperature & 1 & - & - \\
& Trip Number & 0.798 & 1 & 1 \\
\hline \multirow{4}{*}{ Weekend } & Trip Length & 0.611 & 0.585 & Trip Length \\
& Variables & Temperature & Trip Number & \\
\cline { 2 - 5 } & Temperature & 1 & & 1 \\
& Trip Number & 0.797 & 1 & Trip Length \\
& Trip Length & 0.731 & 0.878 & \\
All Year & Variables & Temperature & Trip Number & 1 \\
\cline { 2 - 5 } & Temperature & 1 & & \\
& Trip Number & 0.796 & 0.549 & \\
& Trip Length & 0.521 & & \\
\hline
\end{tabular}

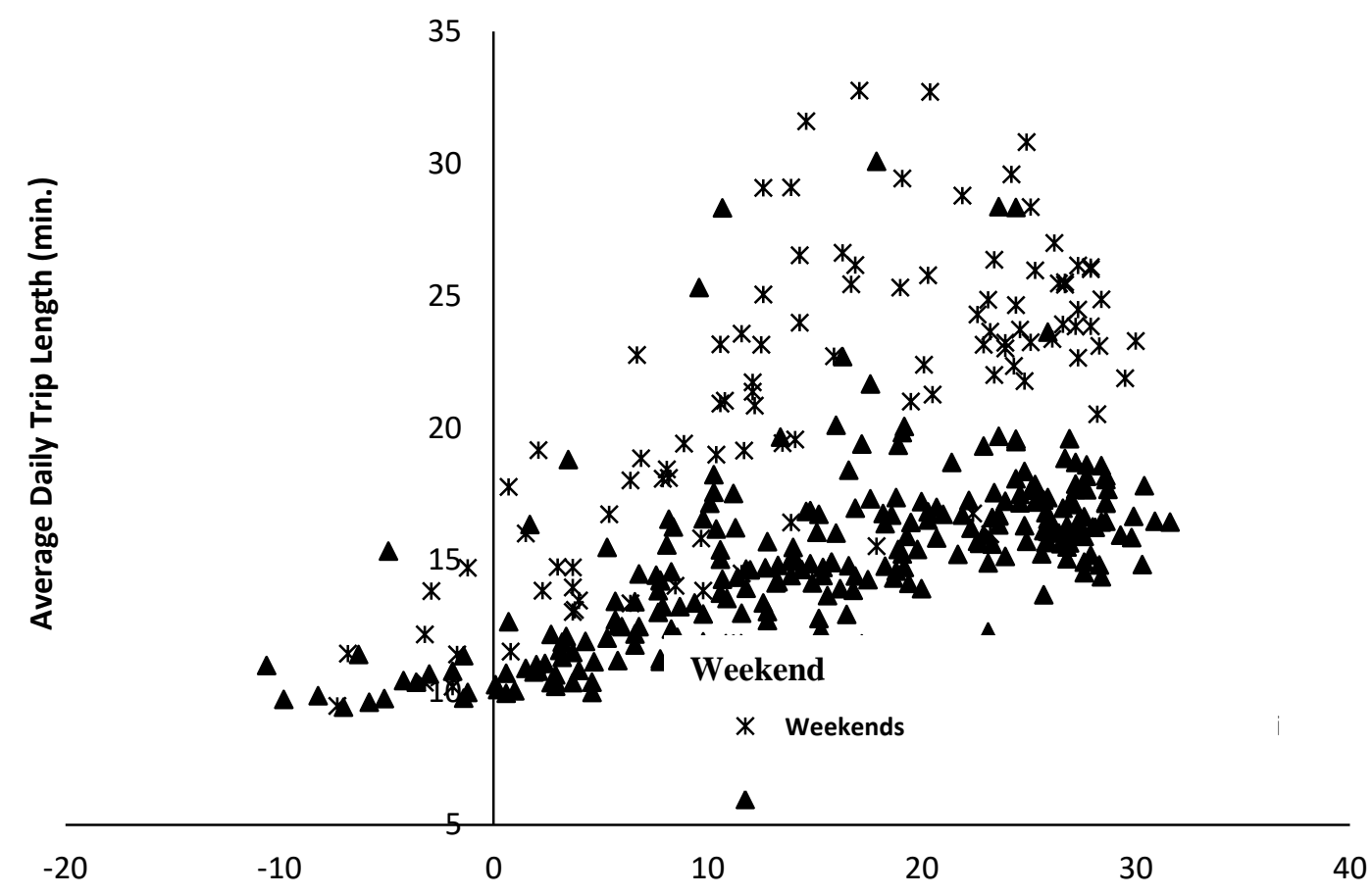

Average Daily Temperature $\left({ }^{\circ} \mathrm{C}\right)$

Figure 9. The relation among trip number, average monthly temperature and months. 


\section{Conclusions and Suggestions}

The growing in Bikesharing Systems causes many problems such as demand, safety, effectiveness, cost etc. For this purpose, nowadays many studies are conducted by the planners, researchers and decision makers to find best solutions to mentioned problems. To examine mentioned parameters average trip length and distribution, relation among temperature, trip number and trip length was analyzed and examined for a famous bikesharing system. For this purpose, Capital Bikeshare System is chosen as pilot system to investigate and evaluate. Obtained results and obtained findings can be summarized as given below:

- There is a strong and positive correlation among temperature, trip number and trip length. It means that users have more tendency on bicycle utilization longer trips in good weather conditions.

- Users have higher bicycle utilization rate on weekends than on weekdays.

- It was found that seasonal weather conditions have a great effect on trip numbers and durations. To obtain good performance from a bikesharing system, authorities should provide hourly and daily weather information systems to users in all stations.

- It was obtained that bicycle utilization has a maximum value between 5-10 minutes. This results can be caused by the free utilization duration (30 minutes) of the system for the members.

- Trip length of bicycle users on weekends are affected highly from the temperature (weather conditions) than on weekdays users. This result can be explained by the longer trip durations of the users.

- Users on weekends generally can have different purpose to use bicycle (shopping, travelling, etc). But users on weekdays generally choose bicycle as a transportation mode to go to work.

Nowadays, Bike Sharing Systems (BSS) grow up as an important transportation mode in urban and rural transportation systems. These systems have a significant role about the utilization of public transportation systems in all around the world. To develop a bikesharing system and integrate with other transportation modes, it is necessary to conduct more studies with real-world transportation data. The findings of these studies are very important for decision makers to plan and install new bikesharing systems in other cities all around the world. For this reason, determination of effective parameters on bicycle utilization and bike sharing systems have a great importance for the modal shift in public transportation systems.

\section{References}

Buck, D. and Buehler, R., 2012. Bike lanes and other determinants of capital bikeshare trips. In Proceedings of 91st Transportation Research Board Annual Meeting, Washington, DC, 1-11.

Capitalbikeshare, 2017. https://www.capitalbikeshare.com.

DeMaio, P. 2009. Bike-Sharing: history, impacts, models of provision, and future. Journal of Public Transportation, 12 (4), 41-56.

El-Assi, W., Mahmoud, M. S. and Habib, K. N., 2017. Effects of built environment and weather on bike sharing demand: a station level analysis of commercial bike sharing in Toronto. Transportation, 44 (3), 589-613.

Faghih-Imani, A. and Eluru, N. 2014. Role of bicycle sharing system infrastructure on usage: evidence from Montreal. In Proceedings of the 5th Innovations in Travel Modeling Conference, Baltimore, MD, 1-36.

Faghih-Imani, A. and Eluru, N., 2016. Incorporating the impact of spatio-temporal interactions on bicycle sharing system demand: a case study of New York Citibike System. Journal of Transport Geography, 54, 218-227.

Faghih-Imani, A., Eluru, N., El-Geneidy, A., Rabbat, M. and Haq, U., 2014. How landuse and urban form impact bicycle flows: evidence from the bicycle-sharing system (BIXI). Journal of Transport Geography, 41, 306-314.

Fishman, E., 2015. Bikeshare: a review of recent literature. Transport Reviews. 36 (1), 92113.

Gebhart, K. and Noland, R., 2014. The impact of weather conditions on bikeshare trips in Washington, DC. Transportation, 41 (6), 1205-1225.

Ghasemlou, K., Aydin, M. M. and Yildirim, M. S., 2015. Prediction of pedal cyclists and 
pedestrian fatalities from total monthly accidents and registered private car numbers. Archives of Transport, 34 (2), 2935 .

Gregerson, J., Hepp-Buchanan, M., Rowe, D., Vander Sluis, J., Wygonik, E., Xenakis, M. and McCormack, E., 2010. Seattle Bicycle Share Feasibility Study. University of Washington, College of Build Environment, Department of Urban Planning and Design.

Jäppinen, S., Toivonen, T. and Salonen, M., 2013. Modelling the potential effect of shared bicycles on public transport travel times in Greater Helsinki: An Open Data Approach. Applied Geography. 43 (2013), 13-24.

Krykewycz, G., Puchalsky, C., Rocks, J., Bonnette, B. and Jaskiewicz, F. 2010. Defining a primary market and estimating demand for major bicycle-sharing program in Philadelphia, Pennsylvania. Transportation Research Record: Journal of the Transportation Research Board, 2143, 117-124.

LLC MetroBike 2014. The Bike Sharing World 2014 Year End Data.

http://bikesharing.blogspot.com/2015/01/th e-bike-sharing- world-2014-year-end.html.

Meddin, R. and DeMaio, P., 2015. The BikeSharing world map.

http://www.bikesharingworld.com.

Murphy, E. and Usher, J., 2015. The role of bicycle-sharing in the city: analysis of the Irish experience. International Journal of Sustainable Transportation, 9 (2), 116-125.

Nair, R., Miller-Hooks, E., Hampshire, R. C., and Bušić, A., 2013. Large-Scale vehicle sharing systems: analysis of Vélib'. International Journal of Sustainable Transportation, 7 (1), 85-106.

Otero, I., Nieuwenhuijsen, M. J. and Rojas-Rueda, D., 2018. Health impacts of bike sharing systems in Europe. Environment international, 115, 387-394.

Ranaiefar, F. and Rixey, R. A., 2016. Bike sharing ridership forecast using structural equation modeling. In Proceedings of Transportation Research Board 95 ${ }^{\text {th }}$ Annual Meeting No. 16-657, 22p.

Rixey, R., 2013. Station-level forecasting of bikesharing ridership: Station Network Effects in Three US Systems. Transportation Research Record: Journal of the Transportation Research Board, 2387, 46-55.

Saplığlu, M. and Aydın, M. M. 2018. Choosing safe and suitable bicycle routes to integrate cycling and public transport systems. Journal of Transport \& Health, 117.

Shaheen, S., Cohen A. and Martin, E., 2013. Public bike sharing in North America: Early operator understanding and emerging trends, Transportation Res. Record, 2387, 83-92.

Shaheen, S., Guzman, S. and Zhang, H. 2010. Bikesharing in Europe, the Americas, and Asia Past, present, and future. Transp. Res. Rec., 2143, 159-167.

Wikipedia.org 2015. List of bicycle-sharing systems.

https://en.wikipedia.org/wiki/List_of_bicycl e-sharing_systems.

Zhang, Y. and Mi, Z., 2018. Environmental benefits of bike sharing: A big data-based analysis. Applied Energy, 220, 296-301.

Zhang, Y., Brussel, M. J. G., Thomas, T. and van Maarseveen, M. F. A. M., 2018. Mining bike-sharing travel behavior data: An investigation into trip chains and transition activities. Computers, Environment and Urban Systems, 69 , 39-50. 